\title{
The Research of College Student Entrepreneurship Education based on E-commerce Platform
}

\author{
Mengqing Feng ${ }^{1,2, a}$, \\ ${ }^{1}$ School of Information Engineering, Zhengzhou University of Industrial Technology, \\ Zhengzhou Henan 451150, PR China \\ ${ }^{2}$ Machine learning and Data researching Institute, Zhengzhou University of Industrial Technology, \\ Zhengzhou Henan 451150, PR China \\ a903901419@qq.com
}

Keywords: Entrepreneurship education; E-Commerce; College students; Network

\begin{abstract}
In the age of network economy, it is necessary to bring e-commerce into campus and combine it with education. In this paper, on the basis of summarizing the development of entrepreneurship education in colleges and universities at home and abroad, combining e-commerce business of college students questionnaire, put forward specific entrepreneurial education training objectives, to build college students e-commerce venture education mode; Enhance the teaching staff of education, and cultivate students' e-commerce entrepreneurial practice ability; In order to improve the entrepreneurial ability of university students based on the e-commerce platform, we should strive for the corresponding supporting policies and build up the college e-commerce platform.
\end{abstract}

\section{Introduction}

Education is a kind of entrepreneurial comprehensive quality that cultivates people's entrepreneurial consciousness, entrepreneurial thinking, entrepreneurial skills, etc., and finally makes the educated person have a certain entrepreneurial ability of education. The "third passport", known as education by UNESCO, is given equal status as the academic education and professional education[1-4].

The status quo of foreign entrepreneurship education. America is at the forefront of entrepreneurship education. In 1967, the United States introduced the introduction of education in university education, which has formed a relatively perfect system structure and has the characteristics of flexibility and variety. Successfully on the whole, American colleges and universities entrepreneurship education for college students, is the government, universities and the intermediary (the venture capitalist, accountants, bankers, etc.), the common effort of entrepreneurs and college students. The cohesion of the American social forces has contributed to the success of American college students' entrepreneurial education. Of course, the development of American colleges and universities has also undergone a long process, from teaching institutions to research and development to entrepreneurial universities[5-8]. This series of transformation has promoted the entrepreneurship of college students, while the entrepreneurial activity of college students has promoted the development of university college students' entrepreneurship education. Entrepreneurship education of university is opened to the early 21 st century, has reached more than 1100 , the university is not only the entrepreneurship education as the leading way of the students' future development, but also held related to entrepreneurship education practice, will venture education into the deeper.

The current situation of domestic entrepreneurship education. The first "tsinghua university entrepreneurship program competition" initiated by the graduate students of tsinghua university in 1997 is regarded as the signal of China's official rise of college students' independent entrepreneurial activity. Since then, the competition for college students has been held to create a good entrepreneurial opportunity and environment for students, laying the foundation for the development of education. Especially in recent years, our country some large and medium-sized 
cities have launched to encourage college students entrepreneurship policy, and has set up some college students' entrepreneurship education projects, local governments also increased spending on entrepreneurship education, thus it can be seen for the importance of entrepreneurship education in our country. Although China's startup education started late, some scholars have also proposed the education model with Chinese characteristics, such as Table 1.

Table 1 The main Entrepreneurship education model of China

\begin{tabular}{|c|c|}
\hline The model of entrepreneurship education & The main school \\
\hline $\begin{array}{c}\text { Focus on training students' } \\
\text { entrepreneurial innovation ability education }\end{array}$ & Renmin University of China \\
\hline $\begin{array}{c}\text { Focus on improving students' entrepreneurial } \\
\text { skills education }\end{array}$ & Beihang University \\
\hline Mixed mode & Shanghai Jiao Tong University \\
\hline
\end{tabular}

With the deepening of exchanges at home and abroad, the education mode of entrepreneurship in China is gradually moving towards the all-school mixed mode from the traditional focus mode. However, the education model of China's entrepreneurship is still single, without obvious features, and the system is not perfect, and the relevant mechanism is not well established. It can be seen that the education model of entrepreneurship in China cannot meet the needs of reality, and it needs further development and perfection.

\section{Research and analysis of education, college students' e-business startup}

In order to understand the situation of college students' e-commerce entrepreneurship education, the corresponding questionnaire was developed, and the time of questionnaire survey was 1 May 2014.A total of 380 questionnaires were issued, 360 were recovered, and 344 were valid questionnaires. In the effective questionnaire, there were 206 women and 138 males. The survey respondents were mainly senior students, accounting for 72.79 percent. And the main focus of the study is e-commerce, computer science and management, accounting for $75 \%$.

University student entrepreneurship education situation. Basic situation of college students accepting the education entrepreneurship. According to the statistics, only 162 interviewees have received courses related to entrepreneurship education, accounting for 47.09 percent, while those who have not received the related courses account for 52.91 percent. Entrepreneurship education's understanding of the necessary degree of entrepreneurship. Regardless of whether or not you have taken a course on entrepreneurship education, nearly 90 percent of respondents think that education is necessary to start a business, and more than 30 percent say it is necessary. Entrepreneurship education's key knowledge unit.

Through the research, it can be clearly understood that college students think that the basic common sense, skills and methods of starting a business are the most important to start a business, accounting for 30.81 percent, followed by communication and marketing skills. And college students think that the knowledge module of entrepreneurship policy is the least important, accounting for only 5.81 percent. From the uneven data, it can be clear that different students have different cognitive importance to the theoretical knowledge of entrepreneurship education, which requires the corresponding guidance from colleges and universities.

The present situation of college students' e-commerce entrepreneurship. The degree of cognition of college students on e-commerce entrepreneurship.

From the surveyed students' understanding of e-commerce entrepreneurship[9-10], 50. 34\% of students think e-commerce web sites and online store is business entrepreneurship, opened the network of the company accounted for $16.55 \%$, and $25.52 \%$ of the considered multimedia project development frontier. It can be seen that different respondents have different perceptions of e-commerce entrepreneurship. (2) Analysis of college students' e-commerce entrepreneurial willingness. In the data survey, only 6.9 percent of respondents were uninterested, and most of the students surveyed were interested in starting a business, but for various reasons, there was no action. 
Therefore, college students have rational thinking about e-commerce entrepreneurship. (3) college students' self-evaluation of the requirements and abilities required for e-business start-ups. Research shows that the top 3 competencies are: personal marketing, interest and entrepreneurial ideas. In respect of entrepreneurial ability of self-evaluation, $23.45 \%$ of college students think they have no ability to e-commerce business, $34.48 \%$ of the students think that some aspects need to strengthen, only 1 people think is fully capable of conducting e-commerce business. This shows that college students are not well prepared for starting their own businesses. Maybe this is why college students are more cautious about starting a business.(4) difficulties faced by college students in e-commerce. From the comparison of data, it is not difficult to find that the difficulties of starting a business can be summarized as the following three points: first, it is difficult to combine the business of entrepreneurship education with e-commerce practice. Although some universities now have to carry out the relevant business education, but the teachers, students do not take the weak, the lack of entrepreneurial atmosphere, and the lack of practice teaching, caused many fans has been blocked in the threshold of entrepreneurship. In entrepreneurship education or related e-commerce courses, students are unable to carry out practical simulation, have no experience accumulation, greatly reduce students' entrepreneurial interest and success rate of entrepreneurship. The second is the difficult choice of entrepreneurial projects and the lack of funds. It is a fundamental problem for college students to judge how to distinguish college students in the face of so many entrepreneurial projects. The lack of funds is a common problem for schools, societies and governments. In the face of entrepreneurial college students, the government should provide formal loan policies, fund support and preferential policies to encourage more college students to start their own businesses.

\section{Suggestions for the implementation of education of e-commerce entrepreneurship in colleges and universities}

Construct the education model for college students' e-commerce entrepreneurship. Influence of examination-oriented education, colleges and universities for attaching too much importance to theoretical knowledge, neglect the cultivation of the college students' practice ability, neglect the students' ability to innovate, to cultivate the college graduates bad at operation, difficult to have a foothold in society. Especially for the electronic commerce industry, faced with the ever-changing environment, colleges and universities should be to improve the ability of the college students' employment, entrepreneurship for entrepreneurial education training objectives, to make graduates talent not only theoretical knowledge, and innovation, risk-taking, electronic commerce, professional practical ability.

Although the development of education in China has been developing rapidly, there is still a large gap compared with the development of foreign countries. For the start-up education of the primary stage, we should construct the education system model suitable for college students and e-commerce specialty in China.

Cultivate students' ability of e-business entrepreneurship. The quality of teachers is the basis of talent cultivation. Therefore, universities should encourage the training of education teaching staff and constantly update the concept of teachers.

Colleges and universities can cooperate with e-business enterprises, and regularly invite successful entrepreneurs to communicate with teachers and enrich the level of entrepreneurship of teachers. At the same time, it is also possible to encourage entrepreneurial teachers to start their own business and share the practical experience with students.

College students not only need to learn entrepreneurial knowledge, but also need to accumulate their own entrepreneurial experience and possess good entrepreneurial practice ability. Schools can undertake e-commerce venture competitions and other activities, will have the same interest in entrepreneurship in the direction of the student team composed of guidance, can not only improve the students' interpersonal skills, but to let students combining theory knowledge and practice, cultivate students' practical operation ability, accumulate experience in the practice of e-commerce business.

Build a college e-commerce platform. In the implementation and improvement of education, it 
is necessary to have a lot of joint management, and the support of policy is a very important link. On the one hand, actively organize entrepreneurial activities, encourage students to carry out entrepreneurial practice, and participate in national entrepreneurship competitions, and continuously improve the entrepreneurial ability of university students; On the other hand, the establishment of college students' entrepreneurship park, giving students entrepreneurship and practice places, and equipped with professional teachers to carry out entrepreneurial guidance, with good policies and related management to support students. In addition, the establishment of a college students' venture fund provides certain financial support for college students who want to start a business.

\section{Conclusion}

Startup education will be the hot spot and trend of education at home and abroad. Entrepreneurship education in our country is still in its infancy, therefore, we need to learn from advanced experience at home and abroad, in the school, society and government, under the joint collaboration of clear training objectives, building the training mode, training teachers, in order to cultivate a good entrepreneurial literacy and e-commerce business practice ability of a new generation of college students.

\section{References}

[1] Celia Whitchurch, George Gordon. Diversifying Academic and Professional Identities in Higher Education: Some management challenges[J]. Tertiary Education \& Management, (2010), No.16(2).P.129-144.

[2] Findlow S. Higher education change and professional-academic identity in newly 'academic' disciplines: the case of nurse education[J]. Higher Education,( 2012), No.63(1).P.117-133.

[3] Higgins K, Harreveld R E. Professional development and the university casual academic: integration and support strategies for distance education[J]. Distance Education, (2013), No.34(2).P.189-200.

[4] Arandia M, Alonso I, Cabo A. The Professional and the Academic World Learning Together in Higher Education[J]. Opción Revista De Ciencias Humanas Y Sociales, (2016), No.32(7).P. 118-137.

[5] Marchese T. Entrepreneurial Universities[J]. Economic Development Quarterly, (2013), No.27(1).P.40-55.

[6] Urbano D, Guerrero M. Entrepreneurial Universities Socioeconomic Impacts of Academic Entrepreneurship in a European Region[J]. Economic Development Quarterly, (2013), No.27(1).P.40-55..

[7] Guerrero M, Urbano D, Cunningham J, et al. Entrepreneurial universities in two European regions: a case study comparison[J]. Journal of Technology Transfer, (2014), No.39(3).P.415-434..

[8] Guerrero M, Urbano D, Fayolle A. Entrepreneurial activity and regional competitiveness: evidence from European entrepreneurial universities[J]. Journal of Technology Transfer, (2016), No.41(1).P.105-131.

[9] Z.Liu, C.Zhang. Research on Entrepreneurship Education Based on E-Commerce[C]// International Conference on Information and Management Engineering. Springer Berlin Heidelberg, (2011).P.381-388.

[10]Bai D. Campus E-commerce Entrepreneurial Mode Analysis[J]. Agriculture Network Information, (2016). 